\title{
Total phenols, ascorbic acid, $\beta$-carotene and lycopene in Portuguese wild edible mushrooms and their antioxidant activities
}

\author{
Lillian Barros ${ }^{\text {a }}$, Maria-João Ferreira ${ }^{\mathrm{a}, \mathrm{b}}$, Bruno Queirós ${ }^{\mathrm{a}, \mathrm{b}}$, \\ Isabel C.F.R. Ferreira ${ }^{a, *}$, Paula Baptista ${ }^{\text {a }}$ \\ a CIMO-Escola Superior Agrária, Instituto Politécnico de Bragança, Campus de Sta. Apolónia, Apartado 1172, 5301-855 Bragança, Portugal \\ ${ }^{\mathrm{b}}$ Escola Superior de Saúde, Instituto Politécnico de Bragança, Av. D. Afonso V, 5300-121 Bragança, Portugal
}

Received 2 February 2006; received in revised form 9 May 2006; accepted 17 July 2006

\begin{abstract}
The antioxidant activities of three Portuguese wild edible mushroom species, Leucopaxillus giganteus, Sarcodon imbricatus, andAgaricus arvensis, were evaluated. Methanolic extracts were screened for their reducing power, 2,2-diphenyl-1-picrylhydrazyl (DPPH) radicalscavenging capacity, inhibition of erythrocytes hemolysis and antioxidant activity using the $\beta$-carotene linoleate model system. The amounts of ascorbic acid, $\beta$-carotene and lycopene found in the mushroom extracts were very low. Otherwise, the high contents of phenolic compounds might account for the good antioxidant properties found in all species. L. giganteus had the highest content of phenols and proved to be the most active, presenting lower $\mathrm{EC}_{50}$ values in all the antioxidant activity assays.
\end{abstract}

(C) 2006 Elsevier Ltd. All rights reserved.

Keywords: Mushrooms; Antioxidant; Phenolics; Ascorbic acid; Beta-carotene; Lycopene

\section{Introduction}

Free radical formation is associated with the normal natural metabolism of aerobic cells. The oxygen consumption inherent in cell growth leads to the generation of a series of oxygen free radicals. The interaction of these species with molecules of a lipidic nature produces new radicals: hydroperoxides and different peroxides (Aust \& Sringen, 1982; Pryor, Lightsey, \& Prier, 1982; Torel, Cillard, \& Cillard, 1986). This group of radicals (superoxide, hydroxyl and lipoid peroxides) may interact with biological systems in a clearly cytotoxic manner. In this respect, flavonoids and phenols have been shown to possess an important antioxidant activity toward these radicals, which is principally based on the redox properties of their phenolic hydroxyl groups and the structural relationships between different parts of their chemical structure (Bors \& Saran, 1987; Vis-

\footnotetext{
* Corresponding author. Tel.: +351 273303219; fax: +351 273325405.

E-mail address: iferreira@ipb.pt (I.C.F.R. Ferreira).
}

ioli, Bellomo, \& Galli, 1998a, Visioli, Bellosta, \& Galli, 1998b). Free radicals and their uncontrolled production, in fact, are responsible for several pathological processes, such as certain tumours (prostate and colon cancers) (Keys, 1995) and coronary heart disease (Lipworth, Martinez, Angell, Hsien, \& Trichopoulos, 1997).

In the past few years, the suspected toxicity of some synthetic compounds used in food has raised interest in natural products (Fukushima \& Tsuda, 1985; Stone, Leclair, Ponder, Bagss, \& Barret-Reis, 2003). Some industries, such as those related to food additive production, cosmetics, and pharmaceuticals, have increased their efforts in preparing bioactive compounds from natural products by extraction and purification. Antioxidant compounds can scavenge free radicals and increase shelf life by retarding the process of lipid peroxidation, which is one of the major reasons for deterioration of food products during processing and storage (Halliwell, 1997; Halliwell \& Gutteridge, 1999). Thus a need for identifying alternative natural and safe sources of food antioxidants has been created, and 
the search for natural antioxidants, especially of plant origin, has notably increased in recent years (Skerget et al., 2005).

Vegetables and fruits are rich sources of antioxidants, such as vitamin A, vitamin C, vitamin E, carotenoids, polyphenolic compounds and flavonoids (Diplock et al., 1998), which prevent free radical damage, reducing risk of chronic diseases. Thus, the consumption of dietary antioxidants from these sources is beneficial in preventing cardiovascular diseases, especially atherosclerosis $(\mathrm{Hu}, 2000)$.

Mushrooms have been used for traditional foods and medicines in Asia (Chang, 1996). Mushrooms contain various polyphenolic compounds recognized as an excellent antioxidant due to their ability to scavenge free radicals by single-electron transfer (Hirano et al., 2001). Some common edible mushrooms, which are widely consumed in Asian culture, have currently been found to possess antioxidant activity, which is well correlated with their total phenolic content (Cheung \& Cheung, 2005; Cheung, Cheung, \& Ooi, 2003; Lo \& Cheung, 2005; Mau, Chang, Huang, \& Chen, 2004, 2002; Yang, Lin, \& Mau, 2002; Yen \& Hung, 2000).

Recently, we described the first study on the antioxidant activity of Portuguese wild edible mushrooms (Lactarius deliciosus and Tricholoma portentosum), comparing the entire mushroom, the cap and stipe $\mathrm{DPPH}^{-}$-scavenging capacities and reducing powers (Ferreira, Baptista, VilasBoas, \& Barros, 2007). Herein, we report the antioxidant activity of three new Portuguese wild edible mushroom species (Leucopaxillus giganteus, Sarcodon imbricatus, Agaricus arvensis), and their correlation with phenol, ascorbic acid, beta-carotene and lycopene contents. For the screening of mushroom antioxidant properties, we evaluated their reducing power, DPPH radical scavenging activity and inhibition of erythrocyte hemolysis, and we also used the $\beta$-carotene linoleate model system.

\section{Materials and methods}

\subsection{Standards and reagents}

Standards BHA (2-tert-butyl-4-methoxyphenol), TBHQ (tert-butylhydroquinone), L-ascorbic acid, $\alpha$-tocopherol and gallic acid were purchased from Sigma (St. Louis, MO, USA). 2,2-Diphenyl-1-picrylhydrazyl (DPPH) was obtained from Alfa Aesar (Ward Hill, MA, USA). All other chemicals were obtained from Sigma Chemical Co. (St. Louis, MO, USA). Methanol was obtained from Pronalab (Lisbon, Portugal). Water was treated in a MiliQ water purification system (TGI Pure Water Systems, USA).

\subsection{Samples}

Samples of $L$. giganteus and A. arvensis were colleted under grassland whereas $S$. imbricatus was collected under live pine trees (Pinus sp.), in Bragança (northeast of Portu- gal), in autumn 2005. After collection, the mushrooms were grouped by taxon and were air-dried in a liophylizator (Ly8-FM-ULE, Snijders, HOLLAND) before analysis. Taxonomic identification was done according to several authors (Bon, 1988; Courtecuisse, 1999; Courtecuisse \& Duhem, 1995; Marchand, 1971-1986; Moser, 1983) and representative voucher specimens were deposited at the herbarium of Escola Superior Agrária of Instituto Politécnico de Bragança.

\subsection{Sample preparation}

A fine dried mushroom powder (20 mesh) sample (5 g) was continuously extracted with methanol in a Soxhlet apparatus for $24 \mathrm{~h}$. The methanolic extract was evaporated to dryness at $40{ }^{\circ} \mathrm{C}$ and redissolved in methanol at a concentration of $5 \mathrm{mg} / \mathrm{ml}$, and stored at $4{ }^{\circ} \mathrm{C}$ prior to further use.

\subsection{Determination of antioxidant components}

Phenolic compounds in the mushroom methanolic extracts were estimated by a colorimetric assay, based on procedures described by Singleton and Rossi with some modifications (Singleton \& Rossi, 1965). Briefly, $1 \mathrm{ml}$ of sample was mixed with $1 \mathrm{ml}$ of Folin and Ciocalteu's phenol reagent. After $3 \mathrm{~min}, 1 \mathrm{ml}$ of saturated sodium carbonate solution was added to the mixture and it was adjusted to $10 \mathrm{ml}$ with distilled water. The reaction was kept in the dark for 90 min, after which the absorbance was read at $725 \mathrm{~nm}$ (Analytikijena 200-2004 spectrophotometer). Gallic acid was used to calculate the standard curve $(0.01-$ $0.4 \mathrm{mM}$ ). Estimation of the phenolic compounds was carried out in triplicate. The results were mean values \pm standard deviations and expressed as $\mathrm{mg}$ of gallic acid equivalents (GAEs) per $\mathrm{g}$ of extract.

Ascorbic acid was determined according to the method of Klein and Perry (1982). The dried methanolic extract $(100 \mathrm{mg}$ ) was extracted with $10 \mathrm{ml}$ of $1 \%$ metaphosphoric acid for $45 \mathrm{~min}$ at room temperature and filtered through Whatman No. 4 filter paper. The filtrate $(1 \mathrm{ml})$ was mixed with $9 \mathrm{ml}$ of 2,6-dichlorophenolindophenol and the absorbance was measured within $30 \mathrm{~min}$ at $515 \mathrm{~nm}$ against a blank. Content of ascorbic acid was calculated on the basis of the calibration curve of authentic L-ascorbic acid $(0.020$ $0.12 \mathrm{mg} / \mathrm{ml}$ ). The assays were carried out in triplicate; the results were mean values \pm standard deviations and expressed as $\mathrm{mg}$ of ascorbic acid/g of extract.

$\beta$-Carotene and lycopene were determined according to the method of Nagata and Yamashita (1992). The dried methanolic extract $(100 \mathrm{mg})$ was vigorously shaken with $10 \mathrm{ml}$ of acetone-hexane mixture (4:6) for $1 \mathrm{~min}$ and filtered through Whatman No. 4 filter paper. The absorbance of the filtrate was measured at 453, 505, 645 and $663 \mathrm{~nm}$. Contents of $\beta$-carotene and lycopene were calculated according to the following equations: lycopene $(\mathrm{mg} /$ $100 \mathrm{ml})=-0.0458 \mathrm{~A}_{663}+0.372 \mathrm{~A}_{505}-0.0806 \mathrm{~A}_{453} ; \beta$-car- 
otene $(\mathrm{mg} / 100 \mathrm{ml})=0.216 \mathrm{~A}_{663}-0.304 \mathrm{~A}_{505}+0.452 \mathrm{~A}_{453}$. The assays were carried out in triplicate; the results were mean values \pm standard deviations and expressed as $\mathrm{mg}$ of carotenoid/g of extract.

\subsection{Reducing power assay}

The reducing power was determined according to the method of Oyaizu (1986). Various concentrations of mushroom methanolic extracts $(2.5 \mathrm{ml})$ were mixed with $2.5 \mathrm{ml}$ of $200 \mathrm{mM}$ sodium phosphate buffer (pH 6.6) and $2.5 \mathrm{ml}$ of $1 \%$ potassium ferricyanide. The mixture was incubated at $50{ }^{\circ} \mathrm{C}$ for $20 \mathrm{~min}$. After $2.5 \mathrm{ml}$ of $10 \%$ trichloroacetic acid $(\mathrm{w} / \mathrm{v})$ were added, the mixture was centrifuged at $1000 \mathrm{rpm}$ for $8 \mathrm{~min}$ (Centorion K24OR-2003 refrigerated centrifuge). The upper layer $(5 \mathrm{ml})$ was mixed with $5 \mathrm{ml}$ of deionised water and $1 \mathrm{ml}$ of $0.1 \%$ of ferric chloride, and the absorbance was measured spectrophotometrically at $700 \mathrm{~nm}$. The assays were carried out in triplicate and the results expressed as mean values \pm standard deviations. The extract concentration providing 0.5 of absorbance $\left(\mathrm{EC}_{50}\right)$ was calculated from the graph of absorbance at $700 \mathrm{~nm}$ against extract concentration. BHA and $\alpha$-tocopherol were used as standards.

\subsection{DPPH radical-scavenging assay}

The capacity to scavenge the "stable" free radical DPPH' was monitored according to the method of Hatano, Kagawa, Yasuhara, and Okuda (1988). Various concentrations of methanolic extracts from mushrooms $(0.3 \mathrm{ml})$ were mixed with $2.7 \mathrm{ml}$ of methanolic solution containing DPPH radicals $\left(6 \times 10^{-5} \mathrm{~mol} / \mathrm{l}\right)$. The mixture was shaken vigorously and left to stand for $60 \mathrm{~min}$ in the dark (until stable absorption values were obtained). The reduction of the DPPH radical was determined by measuring the absorption at $517 \mathrm{~nm}$. The radical-scavenging activity (RSA) was calculated as a percentage of DPPH discoloration using the equation: \%RSA $=\left[\left(A_{\mathrm{DPPH}}-A_{\mathrm{S}}\right) /\right.$ $\left.A_{\mathrm{DPPH}}\right] \times 100$, where $A_{\mathrm{S}}$ is the absorbance of the solution when the sample extract has been added at a particular level, and $A_{\mathrm{DPPH}}$ is the absorbance of the DPPH solution. The assays were carried out in triplicate and the results expressed as mean values \pm standard deviations. The extract concentration providing 50\% inhibition $\left(\mathrm{EC}_{50}\right)$ was calculated from the graph of RSA percentage against extract concentration. BHA and $\alpha$-tocopherol were used as standards.

\subsection{Assay for erythrocyte hemolysis mediated by peroxyl free radicals}

The antioxidant activity of the mushroom methanolic extracts was measured as the inhibition of erythrocyte hemolysis (Miki, Tamia, Mino, Yamamoto, \& Niki, 1987). Blood was obtained from a male ram (churra galega transmontana) of body weight $\sim 67 \mathrm{~kg}$. Erythrocytes, sepa- rated from the plasma and the buffy coat, were washed three times with $10 \mathrm{ml}$ of $10 \mathrm{mM}$ phosphate buffer saline (PBS) at pH 7.4 (prepared by mixing $10 \mathrm{mM} \mathrm{NaH}{ }_{2} \mathrm{PO}_{4}$ and $\mathrm{Na}_{2} \mathrm{HPO}_{4}$, and $125 \mathrm{mM} \mathrm{NaCl}$ in 11 of distilled water) and centrifuged at $1500 \mathrm{~g}$ for $5 \mathrm{~min}$. During the last washing, the erythrocytes were obtained by centrifugation at $1500 \mathrm{~g}$ for $10 \mathrm{~min} .0 .1 \mathrm{ml}$ of a $20 \%$ suspension of erythro-

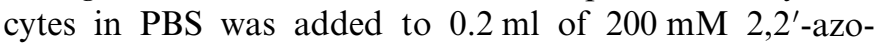
bis(2-amidinopropane)dihydrochloride (AAPH) solution (in PBS) and $0.1 \mathrm{ml}$ of mushroom methanolic extracts of different concentrations. The reaction mixture was shaken gently $(30 \mathrm{rpm})$ while being incubated at $37^{\circ} \mathrm{C}$ for $3 \mathrm{~h}$. The reaction mixture was diluted with $8 \mathrm{ml}$ of PBS and centrifuged at $3000 \mathrm{~g}$ for $10 \mathrm{~min}$; the absorbance of its supernatant was then read at $540 \mathrm{~nm}$ by a spectrophotometer, after filtration with a syringe filter (cellulose membrane $30 \mathrm{~mm}, 0.20 \mu \mathrm{m}$, Titan). The percentage hemolysis inhibition was calculated by the equation: $\%$ hemolysis inhibition $=\left[\left(A_{\mathrm{AAPH}}-A_{\mathrm{S}}\right) / A_{\mathrm{AAPH}}\right] \times 100$, where $A_{\mathrm{S}}$ is the absorbance of the sample containing the mushroom extract, and $A_{\mathrm{AAPH}}$ is the absorbance of the control sample containing no mushroom extract. The assays were carried out in triplicate and the results expressed as mean values \pm standard deviations. The extract concentration providing $50 \%$ inhibition $\left(\mathrm{EC}_{50}\right)$ was calculated from the graph of hemolysis inhibition percentage against extract concentration. L-ascorbic acid was used as standard.

\subsection{Antioxidant assay using the $\beta$-carotene linoleate model system}

The antioxidant activity of mushroom extracts was evaluated by the $\beta$-carotene linoleate model system (Mi-Yae, Tae-Hun, \& Nak-Ju, 2003). A solution of $\beta$-carotene was prepared by dissolving $2 \mathrm{mg}$ of $\beta$-carotene in $10 \mathrm{ml}$ of chloroform. Two millilitres of this solution were pipetted into a $100 \mathrm{ml}$ round-bottom flask. After the chloroform was removed at $40{ }^{\circ} \mathrm{C}$ under vacuum, $40 \mathrm{mg}$ of linoleic acid, $400 \mathrm{mg}$ of Tween 80 emulsifier and $100 \mathrm{ml}$ of distilled water were added to the flask with vigorous shaking. Aliquots $(4.8 \mathrm{ml})$ of this emulsion were transferred into different test tubes containing $0.2 \mathrm{ml}$ of different concentrations of the mushroom extracts. The tubes were shaken and incubated at $50{ }^{\circ} \mathrm{C}$ in a water bath. As soon as the emulsion was added to each tube, the zero time absorbance was measured at $470 \mathrm{~nm}$ using a spectrophotometer. Absorbance readings were then recorded at $20 \mathrm{~min}$ intervals until the control sample had changed colour. A blank, devoid of $\beta$-carotene, was prepared for background subtraction. Antioxidant activity was calculated using the following equation: antioxidant activity $=(\beta$-carotene content after $2 \mathrm{~h}$ of assay/initial $\beta$-carotene content $) \times 100$. The assays were carried out in triplicate and the results expressed as mean values \pm standard deviations. The extract concentration providing $50 \%$ antioxidant activity $\left(\mathrm{EC}_{50}\right)$ was calculated from the graph of antioxidant activity percentage against extract concentration. TBHQ was used as standard. 


\section{Results and discussion}

\subsection{Determination of antioxidant components}

Table 1 shows the phenol, ascorbic acid, $\beta$-carotene and lycopene concentration in the mushroom extracts. Whereas total phenols were the major antioxidant components found in the mushroom extracts, ascorbic acid was found in small amounts $(0.13-0.35 \mathrm{mg} / \mathrm{g})$, and $\beta$-carotene and lycopene were only found in vestigial amounts $(<3 \mu \mathrm{g} / \mathrm{g})$, which is in agreement with other authors (Mau, Lin, \& Song, 2002). These antioxidants were determined in different mushrooms but ascorbic acid and $\beta$-carotene were not detected by spectrophotometry and HPLC, respectively. L. giganteus extracts showed the highest phenolic content $(6.29 \pm 0.20 \mathrm{mg} / \mathrm{g})$; the amount found in $A$. arvensis extracts $(2.83 \pm 0.09 \mathrm{mg} / \mathrm{g})$ was slightly lower than the content found in $S$. imbricatus $(3.76 \pm 0.11 \mathrm{mg} / \mathrm{g})$. The highest content of total phenols in the L. giganteus extracts might account for the better results found for their antioxidant activity. In fact, it had been reported that the antioxidant activity of plant materials is well correlated with the content of phenolic compounds. Polyphenols, such as BHT (butylated hydroxytoluene) and gallate, are known to be effective antioxidants (Velioglu, Mazza, Gao, \& Oomah, 1998).

\subsection{Reducing power assay}

Fig. 1 shows the reducing power of mushroom methanolic extracts as a function of their concentration. In this assay, the yellow colour of the test solution changes to various shades of green and blue, depending on the reducing power of each compound. The presence of reducers (i.e. antioxidants) causes the conversion of the $\mathrm{Fe}^{3+} /$ ferricyanide complex used in this method to the ferrous form. Therefore, by measuring the formation of Perl's Prussian blue at $700 \mathrm{~nm}$, we can monitor the $\mathrm{Fe}^{2+}$ concentration; a higher absorbance at $700 \mathrm{~nm}$ indicates a higher reducing power.

The reducing power of the mushroom methanolic extracts increased with concentration. Reducing powers obtained for all the mushrooms were excellent (Fig. 1); at $5 \mathrm{mg} / \mathrm{ml}$ they were above 0.67 and in the order: L. giganteus $>S$. imbricatus $\sim A$. arvensis. At $5 \mathrm{mg} / \mathrm{ml}$, reducing powers of methanolic extracts from wild edible mushrooms were $0.67-1.47$, and at $1 \mathrm{mg} / \mathrm{ml}$ were $0.072-0.26$. Reducing powers of BHA at $3.6 \mathrm{mg} / \mathrm{ml}$ and $\alpha$-tocopherol at $8.6 \mathrm{mg} /$ $\mathrm{ml}$ were only 0.12 and 0.13 , respectively. Methanolic extracts from $A$. arvensis showed only slightly lower reduc-

Table 1

Contents of total phenols, ascorbic acid, $\beta$-carotene and lycopene in the mushroom extract

\begin{tabular}{llll}
\hline & L. giganteus & S. imbricatus & A. arvensis \\
\hline Total phenols $(\mathrm{mg} / \mathrm{g})$ & $6.29 \pm 0.20$ & $3.76 \pm 0.11$ & $2.83 \pm 0.09$ \\
Ascorbic acid $(\mathrm{mg} / \mathrm{g})$ & $0.13 \pm 0.0069$ & $0.16 \pm 0.0072$ & $0.35 \pm 0.0015$ \\
$\beta$-Carotene $(\mu \mathrm{g} / \mathrm{g})$ & $1.88 \pm 0.090$ & $2.53 \pm 0.11$ & $2.97 \pm 0.12$ \\
Lycopene $(\mu \mathrm{g} / \mathrm{g})$ & $0.69 \pm 0.034$ & $1.3 \pm 0.070$ & $1.0 \pm 0.049$ \\
\hline
\end{tabular}

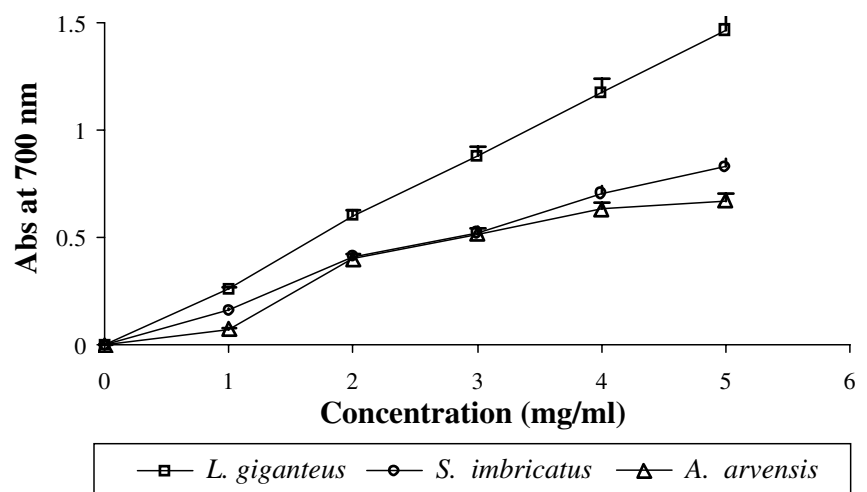

Fig. 1. Reducing power of mushroom methanolic extracts (higher absorbance indicates higher reducing power). Each value is expressed as mean \pm standard deviation $(n=3)$

ing power values than did those from $S$. imbricatus (Fig. 1). It was reported that the reducing properties are generally associated with the presence of reductones, which have been shown to exert antioxidant action by breaking the free radical chain by donating a hydrogen atom (Shimada, Fujikawa, Yahara, \& Nakamura, 1992). Accordingly, L. giganteus might contain higher amounts of reductone, which could react with free radicals to stabilise and block radical chain reactions.

\subsection{Radical-scavenging activity (RSA) assay}

The free radical DPPH' possesses a characteristic absorption at $517 \mathrm{~nm}$ (purple in colour), which decreases significantly on exposure to radical-scavengers (by providing hydrogen atoms or by electron donation). A lower absorbance at $517 \mathrm{~nm}$ indicates a higher radical-scavenging activity of the extract. Free radical-scavenging is one of the known mechanisms by which antioxidants inhibit lipid oxidation. This test is a standard assay in antioxidant activity studies and offers a rapid technique for screening the RSA of specific compounds or extracts (Amarowicz, Pegg, Rahimi-Moghaddam, Barl, \& Weil, 2004).

The RSA values of mushroom methanolic extracts are presented in Fig. 2; results are expressed as the ratio percentage of sample absorbance decrease and the absorbance of DPPH solution in the absence of extract at $517 \mathrm{~nm}$. From the analysis of Fig. 2, we can conclude that the scavenging effects of mushrooms methanolic extracts on DPPH radicals increased with the concentration increase and were excellent for L. giganteus $(100 \%$ at $5 \mathrm{mg} / \mathrm{ml})$, even higher than the scavenging effects of BHA $(96 \%$ at $3.6 \mathrm{mg} / \mathrm{ml})$ and $\alpha$-tocopherol $(95 \%$ at $8.6 \mathrm{mg} / \mathrm{ml})$. The RSA values were good for $S$. imbricatus $(80 \%$ at $5 \mathrm{mg} / \mathrm{ml})$ and moderate for $A$. arvensis $(68.3 \%$ at $5 \mathrm{mg} / \mathrm{ml})$.

\subsection{Assay for erythrocyte hemolysis mediated by peroxyl free radicals}

The oxidative hemolysis in erythrocytes induced by AAPH has been extensively studied as a model for perox- 


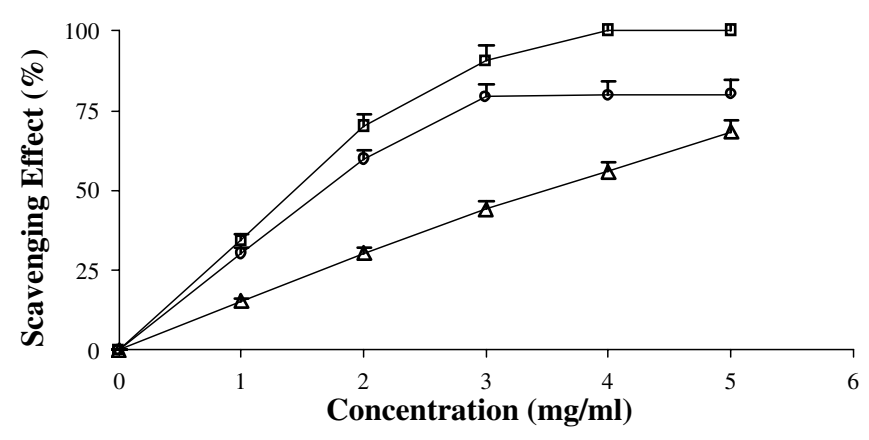

๑- L. giganteus $\multimap$ S. imbricatus $\triangle$ A. arvensis

Fig. 2. Scavenging activity (\%) on DPPH radicals of mushroom methanolic extracts. Each value is expressed as mean \pm standard deviation $(n=3)$.

idative damage in biomembranes (Zhang et al., 1997). AAPH is a peroxyl radical initiator that generates free radicals by its thermal decomposition and will attack the erythrocytes to induce the chain oxidation of lipid and protein, disturbing the membrane organization and eventually leading to hemolysis. In this study, the protective effect of the mushroom extracts on hemolysis by peroxyl radicalscavenging activity was investigated. Fig. 3 shows inhibition percentage of hemolysis, as a result of protection against the oxidative damage of cell membranes of erythrocytes from ram, induced by AAPH. The mushroom extracts inhibited hemolysis of erythrocytes in a concentration-dependent manner. Once more, L. giganteus showed higher protective effect against erythrocytes hemolysis $(72.8 \%$ at $5 \mathrm{mg} / \mathrm{ml})$ than did the other mushrooms $(34.2 \%$ for $S$. imbricatus and $31.8 \%$ for A. arvensis). However, the inhibition percentage of the standard L-ascorbic acid on hemolysis of red blood cells was much higher $(94.6 \%$ at $1 \mathrm{mg} / \mathrm{ml}$ ) than those of mushroom extracts.

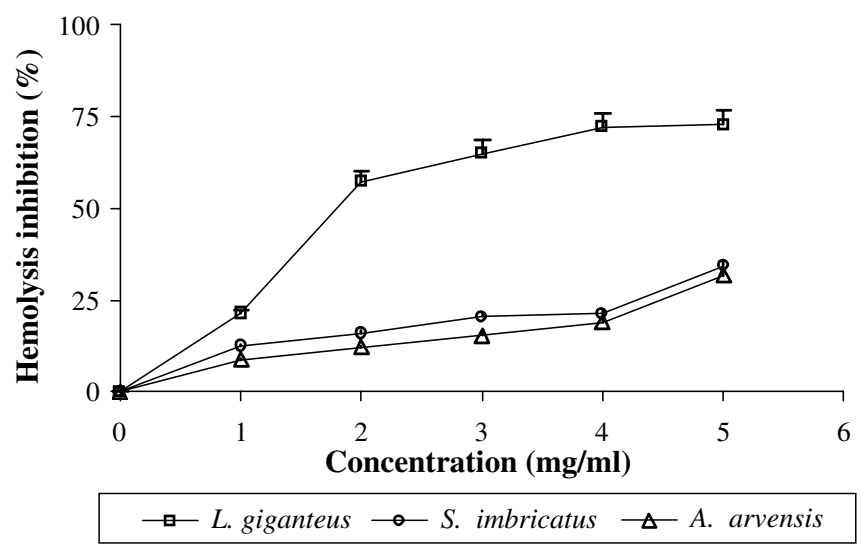

Fig. 3. Hemolysis inhibition (\%) of the mushroom methanolic extracts. Each value is expressed as mean \pm standard deviation $(n=3)$.

\subsection{Antioxidant assay using the $\beta$-carotene linoleate model} system

Fig. 4 shows the antioxidant activity of the mushroom extracts as measured by the bleaching of $\beta$-carotene. The antioxidant activity of carotenoids is based on the radical adducts of carotenoids with free radicals from linoleic acid. The linoleic acid free radical attacks the highly unsaturated $\beta$-carotene models. The presence of different antioxidants can hinder the extent of $\beta$-carotene-bleaching by neutralizing the linoleate-free radical and other free radicals formed in the system (Jayaprakasha, Singh, \& Sakariah, 2001). Accordingly, the absorbance decreased rapidly in samples without antioxidant whereas, in the presence of an antioxidant, they retained their colour, and thus absorbance, for a longer time. Antioxidant activities of $L$. giganteus, $S$. imbricatus and $A$. arvensis extracts increased with their increasing concentration. Their antioxidant activities were $61.4 \%, 54.3 \%$ and $46.7 \%$ at $5 \mathrm{mg} / \mathrm{ml}$, but antioxidant activity of TBHQ standard reached $82.2 \%$ at $2 \mathrm{mg} / \mathrm{ml}$. It is probable that the antioxidative components in the mushroom extracts can reduce the extent of $\beta$-carotene destruction by neutralizing the linoleate free radical and other free radicals formed in the system. Again, $L$. giganteus was the most effective, with an $\mathrm{EC}_{50}$ value of $2 \mathrm{mg} / \mathrm{ml}$.

Table 2 shows the $\mathrm{EC}_{50}$ values for the antioxidant activity assays obtained from each mushroom methanolic extract.

Overall, L. giganteus revealed better antioxidant properties (lower $\mathrm{EC}_{50}$ values) than did either $S$. imbricatus or $A$. arvensis, which is in agreement with the higher content of phenols found in the first species. The $\mathrm{EC}_{50}$ values obtained for reducing power and scavenging effects on DPPH radicals were better than those for hemolysis inhibition mediated by peroxyl free radicals and for the antioxidant activity using the linoleate- $\beta$ carotene system. A relationship between the reducing power, DPPH'-scavenging activity, hemolysis inhibition and $\beta$-carotene-bleaching extent was found, indicating that the mechanisms of action of the extracts for the antioxidant activity may be identical,

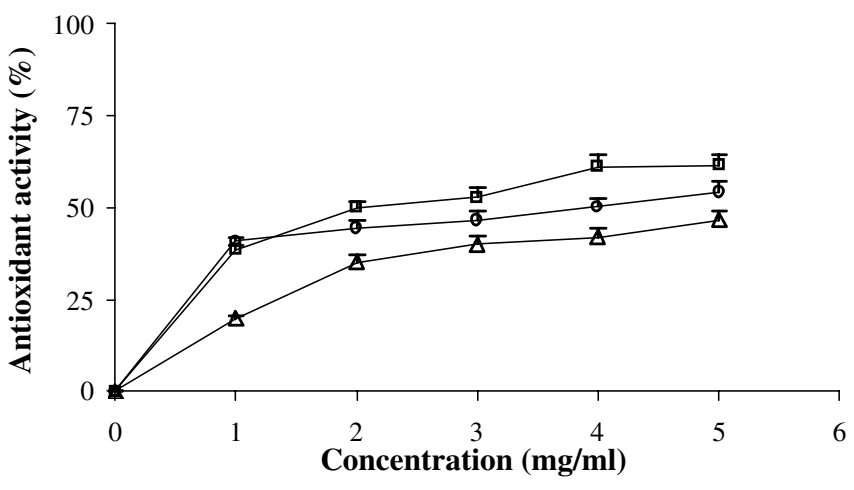

$\rightarrow$ L. giganteus $\multimap$ S. imbricatus $\triangle$ A. arvensis

Fig. 4. Antioxidant activity ( $\%$ ) of the mushroom methanolic extracts by $\beta$-carotene bleaching method. Each value is expressed as mean \pm standard deviation $(n=3)$. 
Table 2

$\mathrm{EC}_{50}$ values $(\mathrm{mg} / \mathrm{ml})$ of mushroom extracts in the antioxidant activity evaluation assays

\begin{tabular}{|c|c|c|c|c|}
\hline Samples & Reducing power $\left(\mathrm{EC}_{50}{ }^{\mathrm{a}}\right)$ & $\mathrm{DPPH}\left(\mathrm{EC}_{50}{ }^{\mathrm{b}}\right)$ & Hemolysis inhibition $\left(\mathrm{EC}_{50}{ }^{\mathrm{c}}\right)$ & $\beta$-Carotene bleaching $\left(\mathrm{EC}_{50}{ }^{\mathrm{d}}\right)$ \\
\hline L. giganteus & 1.71 & 1.44 & 1.80 & 2.00 \\
\hline S. imbricatus & 2.79 & 1.67 & $>5$ & 3.97 \\
\hline A. arvensis & 2.86 & 3.50 & $>5$ & $>5$ \\
\hline
\end{tabular}

${ }^{\mathrm{a}} \mathrm{EC}_{50}(\mathrm{mg} / \mathrm{ml})$ : effective concentration at which the absorbance is 0.5 .

${ }^{\mathrm{b}} \mathrm{EC}_{50}(\mathrm{mg} / \mathrm{ml})$ : effective concentration at which $50 \%$ of DPPH radicals are scavenged.

${ }^{c} \mathrm{EC}_{50}(\mathrm{mg} / \mathrm{ml})$ : effective concentration at which $50 \%$ of the erythrocytes hemolysis are inhibited.

${ }^{d} \mathrm{EC}_{50}(\mathrm{mg} / \mathrm{ml})$ : effective concentration at which the antioxidant activity is $50 \%$.

being related to the content of total phenols. Though other antioxidants were probably present in these mushroom extracts, the amounts of ascorbic acid, $\beta$-carotene and lycopene found in the three Portuguese mushroom extracts were very low, which emphasises the idea that phenolic compounds could make a significant contribution to the mushrooms' antioxidant activity. To our knowledge, the present study is to demonstrate that the antioxidative components in the Portuguese mushrooms extracts can protect the membranes of erythrocytes incubated with AAPH, and can reduce the extent of $\beta$-carotene destruction by neutralizing the linoleate free radicals and other free radicals formed in the system.

\section{Acknowledgements}

The authors are grateful to the Foundation for Science and Technology (POCI/AGR/56661/2004) for financial support of this work.

\section{References}

Amarowicz, R., Pegg, R. B., Rahimi-Moghaddam, P., Barl, B., \& Weil, J. A. (2004). Free-radical scavenging capacity and antioxidant activity of selected plant species from the Canadian prairies. Food Chemistry, 84, $551-562$.

Aust, S. D., \& Sringen, B. A. (1982). Free radicals in biology (Vol. 5). New York: Academic Press.

Bon, M. (1988). In Guia de campo de los Hongos de Europa. Barcelona: Ediciones Omega.

Bors, W., \& Saran, M. (1987). Radical scavenging by flavonoid antioxidants. Free Radical Research Communications, 2, 289-294.

Chang, R. (1996). Functional properties of edible mushrooms. Nutrition Reviews, 54, S91-S93.

Cheung, L. M., \& Cheung, P. C. K. (2005). Mushroom extracts with antioxidant activity against lipid peroxidation. Food Chemistry, 89, 403-409.

Cheung, L. M., Cheung, P. C. K., \& Ooi, V. E. C. (2003). Antioxidant activity and total phenolics of edible mushroom extracts. Food Chemistry, 81, 249-255.

Courtecuisse, R. (1999). In Mushrooms of Britain and Europe. London: HarperCollins Publishers.

Courtecuisse, R., \& Duhem, B. (1995). In Mushrooms and Toadstools of Britain and Europe. London: HarperCollins Publishers.

Diplock, A. T., Charleux, J. L., Crozier-willi, G., Kok, F. J., Rice-Evan, C., \& Roberfroid, M. (1998). Functional food science and defence against reactive oxidative species. British Journal of Nutrition, 80S, S77-S112.

Ferreira, I. C. F. R., Baptista, P., Vilas-Boas, M., \& Barros, L. (2007). Free-radical scavenging capacity and reducing power of wild edible mushrooms from northeast Portugal: individual cap and stipe activity. Food Chemistry, 100, 1511-1516.

Fukushima, N. S., \& Tsuda, H. (1985). Carcinogenity and modification of the carcinogenic response by BHA, BHT and other antioxidants. Critical Reviews in Toxicology, 15, 109-150.

Halliwell, B. (1997). Antioxidants in human health and disease. Annual Review of Nutrition, 16, 33-50.

Halliwell, B., \& Gutteridge, J. M. C. (1999). Free radicals in biology and medicine. United Kingdom: Oxford University Press.

Hatano, T., Kagawa, H., Yasuhara, T., \& Okuda, T. (1988). Two new flavonoids and other constituents in licorice root: their relative astringency and radical scavenging effects. Chemical and Pharmaceutical Bulletin, 36, 2090-2097.

Hirano, R., Sasamoto, W., Matsumoto, A., Itakura, H., Igarashi, O., \& Kondo, K. (2001). Antioxidant ability of various flavonoids against DPPH radicals and LDL oxidation. Journal of Nutritional Science and Vitaminology (Tokyo), 47, 357-362.

$\mathrm{Hu}$, F. B. (2000). Dietary pattern analysis: a new direction in nutritional epidemiology. Current Opinion in Lipidology, 13, 3-9.

Jayaprakasha, G. K., Singh, R. P., \& Sakariah, K. K. (2001). Antioxidant activity of grape seed (Vitis vinifera) extracts on peroxidation models in vitro. Food Chemistry, 73, 285-290.

Keys, A. (1995). Mediterranean diet and public health personal reflection. American Journal of Clinical Nutrition, 61, 1321S-1323S.

Klein, B. P., \& Perry, A. K. (1982). Ascorbic acid and vitamin A activity in selected vegetables from different geographical areas of the United States. Journal of Food Science, 47, 941-945, 948.

Lipworth, L., Martinez, M. E., Angell, J., Hsien, C. C., \& Trichopoulos, D. (1997). Olive oil and human cancer: an assessment of evidence. Preventive Medicine, 26, 181-190.

Lo, K. M., \& Cheung, P. C. K. (2005). Antioxidant activity of extracts from the fruiting bodies of Agrocybe aegerita var. alba. Food Chemistry, 89, 533-539.

Marchand, A. (1971-1986). In Champignons du Nord et du Midi. Tome 1-9. Soc. Mycol. Perpignan: Pyrénées Mediterranéenes.

Mau, J.-L., Chang, C.-N., Huang, S.-J., \& Chen, C.-C. (2004). Antioxidant properties of methanolic extracts from Grifola frondosa, Morchella esculenta and Termitomyces albuminosus mycelia. Food Chemistry, 87, 111-118.

Mau, J.-L., Lin, H.-C., \& Song, S.-F. (2002). Antioxidant properties of several speciality mushrooms. Food Research International, 35, 519-526.

Mi-Yae, S., Tae-Hun, K., \& Nak-Ju, S. (2003). Antioxidants and free radical scavenging activity of Phellinus baumii (Phellinus of Hymenochaetaceae) extracts. Food Chemistry, 82, 593-597.

Miki, M., Tamia, H., Mino, M., Yamamoto, Y., \& Niki, E. (1987). Freeradical chain oxidation of rat read blood cells by molecular oxygen and its inhibition by $\alpha$-tocopherol. Archives of Biochemistry and Biophysics, 258, 373-380.

Moser, M. (1983). In Keys to Agarics and Boleti (Polyporales, Boletales, Agaricales, Russulales). London: Roger Phillips.

Nagata, M., \& Yamashita, I. (1992). Simple method for simultaneous determination of chlorophyll and carotenoids in tomato fruit. Nippon Shokuhin Kogyo Gakkaish, 39(10), 925-928. 
Oyaizu, M. (1986). Studies on products of browning reactions: antioxidative activities of products of browning reaction prepared from glucosamine. Japanese Journal of Nutrition, 44, 307-315.

Pryor, W. A., Lightsey, J. W., \& Prier, D. G. (1982). The production of free radicals in vivo from the action of xenobiotics: the initiation of autooxidation of polyunsaturated fatty acids by nitrogen dioxide and ozone. In Lipid peroxides in Biology and Medicine (pp. 1-22). New York: Academic Press.

Shimada, K., Fujikawa, K., Yahara, K., \& Nakamura, T. (1992). Antioxidative properties of xanthan on the autoxidation of soybean oil in cyclodextrin emulsion. Journal of Agriculture and Food Chemistry, 40, 945-948.

Singleton, V. L., \& Rossi, J. A. Jr., (1965). Colorimetric of total phenolics with phosphomolybdic-phosphotungstic acid reagents. American Journal of Enology and Viticulture, 16, 144-158.

Skerget, M., Kotnik, P., Hadolin, M., Hras, A. R., Simonic, M., \& Knez, Z. (2005). Phenols, proanthocyanidins, flavones and flavonols in some plant materials and their antioxidant activities. Food Chemistry, 89, 191-198.

Stone, W. L., Leclair, I., Ponder, T., Bagss, G., \& Barret-Reis, B. (2003). Infants discriminate between natural and synthetic vitamin E. American Journal of Clinical Nutrition, 77, 899-906.
Torel, J., Cillard, J., \& Cillard, P. (1986). Antioxidant activity of flavonoids and reactivity with peroxy radical. Phytochemistry, 2, 383-385.

Velioglu, Y. S., Mazza, G., Gao, L., \& Oomah, B. D. (1998). Antioxidant activity and total phenolics in selected fruits, vegetables, and grain products. Journal of Agriculture and Food Chemistry, 46, 4113-4117.

Visioli, F., Bellomo, G., \& Galli, C. (1998a). Free-radical-scavenging properties of olive oil polyphenols. Biochemical and Biophysical Research Communications, 247, 60-64.

Visioli, F., Bellosta, S., \& Galli, C. (1998b). Oleuropein, the bitter principle of olives enhances nitric oxide production by mouse macrophages. Life Sciences, 62, 541-546.

Yang, J.-H., Lin, H.-C., \& Mau, J.-L. (2002). Antioxidant properties of several commercial mushrooms. Food Chemistry, 77, 229-235.

Yen, G.-C., \& Hung, C.-Y. (2000). Effects of alkaline and heat treatment on antioxidative activity and total phenolics of extracts from Hsiantsao (Mesona procumbens Hemsl.). Food Research International, 33, 487-492.

Zhang, A., Zhu, Q. Y., Luk, Y. S., Ho, K. Y., Fung, K. P., \& Chen, Z.-Y. (1997). Inhibitory effect of jasmine green tea epicatechin isomers on free radical-induced lysis of red blood cells. Life Sciences, 61, 383-394. 